\title{
The ASEAN Free Trade Agreement and Vietnam's Trade Efficiency
}

\author{
Hai, Nguyen Thi Hong ${ }^{1} \&$ Thang, Doan Ngoc ${ }^{1}$ \\ ${ }^{1}$ Business Faculty, Banking Academy of Vietnam, Hanoi, Vietnam \\ Correspondence: Hai, Nguyen Thi Hong, Business Faculty, Banking Academy of Vietnam, Hanoi, Vietnam. \\ E-mail: hainth@hvnh.edu.vn
}

Received: February 14, 2017

Accepted: March 2, 2017

Online Published: March 24, 2017

doi:10.5539/ass.v13n4p192

URL: https://doi.org/10.5539/ass.v13n4p192

\begin{abstract}
This study employs a stochastic gravity model to estimate the efficiency performance of Vietnam's trade with its main trading partners from 1995-2015. Trade efficiency is measured as the ratio of actual trade volume to the maximum likelihood. Moreover. it analyzes the effects of both natural and man-made trade barriers on trade efficiency. The empirical results suggest that the actual trade of Vietnam appears to be much smaller than a possible efficiency level and that there is large space for further progress. Export efficiency outweighs that of import. Vietnam's ASEAN Free Trade Agreement membership has, in general, improved the trade efficiency, whereas tariffs and domestic devaluation have impaired it. Our findings lead to the recommendation that Vietnam should join more Free Trade Agreements and break down the man-made barriers.
\end{abstract}

Keywords: FTA, Trade Efficiency, Trade Barriers

\section{Introduction}

Free Trade Agreements (FTAs) have become increasingly prevalent since the early 1990s as an effective instrument to foster trade. In the year 2016 the cumulative number of physical FTAs in force was 267. International trade plays an important role in stimulating the Vietnam's economic development. In order to promote international trade, the responsible Vietnamese authorities have dynamically grown the number of FTAs with its trading partners. As of the beginning of year 2017, Vietnam has signed eleven FTAs. Six out of eleven FTAs were countersigned as a member of ASEAN Free Trade Area (AFTA). The trade volume with these countries (China, Korea, Japan, Australia and New Zealand, India, and Chile) has witnessed a substantial rise.

FTAs offer both advantages and disadvantages. In terms of the benefits, trade creation's effect arises from the abolition of trade barriers such as tariffs on domestic goods and those of other members; when it comes to the drawbacks, trade diversion's effect exists due to the birth of some kinds of non-tariff accompanying with FTA that induce production and administrative cost. A large number of seminar works have questioned which effect is dominant. A positive and significant impact on trade flows among members in the European Community was shown by several economists (Aitken, 1973; Abrams, 1980; Brada \& Mendez, 1983). Bergstrand (1985) pointed out insignificant effects, whereas Frankel and Wei (1996) found mixed results. Close to our study of AFTA's effects on Vietnam trade is Le, Nguyen, and Bandara (1996), Nguyen (2009), and Narayan and Nguyen (2016). However, they all used the conventional gravity model in trade analysis proposed by Tinbergen (1962) and found a positive impact of AFTA on Vietnam's bilateral trade. FTAs have always faced various barriers in the execution phase including but not limited to governmental trade barriers, resistance from domestic industrial leaders, opposition from labor syndicates, etc. (Aghdaie et al., 2012; Riasi, 2015). Therefore, in order to have an effective FTA it is necessary to engage all the parties that will be impacted by the FTA before the agreement comes into effect (Riasi \& Amiri Aghdaie, 2013).

In this study, we aim to investigate how AFTA and trade barriers affect Vietnam's trade efficiency. Trade efficiency is defined as the ratio of Vietnam's actual trade to its potential trade, which is estimated with a stochastic frontier gravity model. We simultaneously analyze export and import flow. Our numerical results imply that Vietnam's exports and imports with a lot of its trading partners are far from its efficient level with the former exceeding the latter. Joining AFTA improve the Vietnam's trade efficiency. Man-made trade barriers have been introduced for some goods reasons, but they only benefit some limited sectors. For instance, infant industries in both developed and developing countries have been protected by those barriers under a high level of global competition. In general, it is essential to eradicate man-made trade resistance so as to narrow the gap 
between actual trade and trade frontiers.

\section{Literature Review}

The growth in Vietnam's international trade has motivated economists to find out the determinants of this phenomenon. Le et al. (1996) analyzed the trade between Vietnam and 17 Asia-Pacific Economic Cooperation (APEC) countries. They found that economic size and geographical distance are crucial in driving the intraregional trade volumes. They claimed that artificial barriers to trade reduce their adverse effects on Vietnam's trade compared to the 1980s. Nguyen and Xing (2008) examined the effect of Foreign Direct Investment (FDI) from 23 countries on the Vietnam's exports. Their empirical results suggest that FDI is one of the key factors in determining the boom of Vietnam's exports. Thanh and Duong (2011), however, show that FDI inflow boosts Vietnam's exports but the magnitude is limited. They mainly attribute the rapid growth of Vietnam's exports to the improvement in the level of national competitiveness and in the external trade opportunities. Narayan and Nguyen (2015) investigated the bilateral trade between Vietnam and 54 trading partners in the period 1986-2010. They found out that the impact of trade gravity variables is contingent on trading partners. They proposed that the level of economic development should be focused on when to design and implement trade policy.

All of the above papers utilize the conventional gravity model invented by Tinbergen (1962). Anderson and Wincoop (2003) claimed that the estimates of this model could be biased because the conventional gravity model cannot control the resistances to trade such as distance and official barriers to trade; most of them are hard to quantify and therefore they are added into the unobserved disturbance term (Baier \& Bergstrand, 2009). Our study makes use of the stochastic frontier gravity analysis to solve the problem of with the unobservable resistances to trade. Armstrong (2007) said that this type of method is acceptable and appropriate, and thus can be used to estimate the unobservable resistances to trade. By using two-way errors, our study is closed to research by Nguyen (2009) which applies the Hausman-Taylor method to examine the effect of AFTA on export flows using panel data. But we differ from them in two main points: first, we focus on the trade efficiency; second, we divide trade barriers into natural and man-made categories and this leads to 2-step estimation.

\section{Methodology: Stochastic Frontier Gravity Model and Trade Efficiency}

This paper employs a modified version of gravity model that is one of the main paradigm of numerical analysis on international trade and FTAs' effects. Canonical gravity models estimate the mean effects of driving factors of trade. Actual trade amounts are beneath the highest possibility levels due to the existence of both natural and man-made barriers. As a consequence, the gap between actual and maximum trade always exists and it could be measured by using disturbances with non-zero and non-negative mean. Kalirajan and Findlay (2005) proposed a method to estimate trade potential with gravity model motivated by the seminar works of measuring production possibility frontiers. Trade potential is defined as the highest feasible trade that can be reached without man-made barriers.

As in Armstrong (2007), the form of stochastic frontier gravity equation is given as follows:

$$
X_{i t}=f\left(Y_{i t} ; \beta\right) \exp ^{\left(v_{i t}-u_{i t}\right)}
$$

where $X_{i t}$ is the bilateral trade between Vietnam and country $i, f\left(Y_{i t}, \beta\right)$ captures factors which determine the potential trade $\left(\mathrm{Y}_{\mathrm{it}}\right)$ without man-made resistances - and $\beta$ represents a vector of unknown parameters which will be estimated. Both $u_{i t}$ and $v_{i t}$ are error terms. While the single-sided error term, $u_{i t}$ is technical inefficiency that captures the man-made resistances, $v_{i t}$ represents the impact on trade of the rest of variables. $u_{i t}$ lies between 0 and 1 and it is assumed to have a non-negative truncated normal distribution with a mean of $\mu$ at a $\sigma_{u}^{2}$. The double-sided error term $\mathrm{v}_{\text {it }}$, that is assumed to be normally distributed with a mean of zero and $\sigma_{v}^{2}$, captures the measurement and specification error.

Specifically, we assign the model as follows:

$$
\begin{gathered}
\operatorname{LnEX}_{i t}=\beta_{0}+\beta_{1} \operatorname{LnGDP}_{i t}+\beta_{2} \operatorname{LnGDPVN}_{\mathrm{t}}+\beta_{3} \mathrm{LnD}_{\mathrm{i}}+\beta_{4} \mathrm{LL}_{\mathrm{i}}+\beta_{5} \mathrm{RA}_{\mathrm{i}}+\beta_{6} \mathrm{P}_{\mathrm{it}}+\beta_{7} \mathrm{PVN}_{\mathrm{t}}+\beta_{8} \mathrm{~T}+\mathrm{v}_{\mathrm{it}}-\mathrm{u}_{\mathrm{it}} \\
\mathrm{LnIM}_{\mathrm{it}}=\beta_{0}+\beta_{1} \mathrm{LnGDP}_{\mathrm{it}}+\beta_{2} \mathrm{LnGDPVN}_{\mathrm{t}}+\beta_{3} \mathrm{LnD}_{\mathrm{i}}+\beta_{4} \mathrm{LL}_{\mathrm{i}}+\beta_{5} \mathrm{RA}_{\mathrm{i}}+\beta_{6} \mathrm{P}_{\mathrm{it}}+\beta_{7} \mathrm{PVN}_{\mathrm{t}}+\beta_{8} \mathrm{~T}+\mathrm{v}_{\mathrm{it}}-\mathrm{u}_{\mathrm{it}}
\end{gathered}
$$

Where $\mathrm{EX}_{\mathrm{it}}$ and $\mathrm{IM}_{\mathrm{it}}$ are the actual export and import value of Vietnam with country $\mathrm{i}$ at year $\mathrm{t}$ respectively; $\mathrm{GDP}_{i t}$ and GDPVN ${ }_{\mathrm{t}}$ are the gross domestic product of country $\mathrm{i}$ and Vietnam at year $\mathrm{t}$; GDP is used as a proxy for

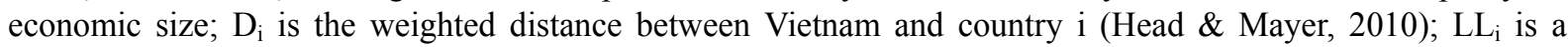
dummy variable, taking value 1 if country $\mathrm{I}$ is landlocked, 0 otherwise; $\mathrm{RA}_{\mathrm{i}}$ is defined as the relative land area between country $i$ and Vietnam; $P_{i t}$ and $P_{V N} N_{t}$ capture the population of country $i$ and Vietnam respectively. $T$ is a time trend variable used to reflect macro-dynamic distresses. Error term $v_{i t}$ is the measurement and specification 
error. Error term $u_{i t}$ represents negative effects on the trade volume because of man-made trade barriers and measure the size of inefficiency of Vietnam trade with country i.

Based on the model assignment, we can now define both the export and import efficiency with a specific trading partner i as follows:

$$
T R E_{i t}=\frac{\exp \left[\operatorname{LnX} X_{i t}\right]}{\exp \left[\operatorname{Lnf}\left(Y_{i t} ; \beta\right)+v_{i t}\right]}=\frac{f\left(Y_{i t} ; \beta\right) \exp \left(v_{i t}-u_{i t}\right)}{f\left(Y_{i t} ; \beta\right) \exp \left(v_{i t}\right)}=\exp \left(-u_{i t}\right)
$$

where $\exp \left(\operatorname{LnX} X_{i t}\right)$ is actual exports or imports and $\exp \left(\operatorname{Lnf}\left(\mathrm{Y}_{\mathrm{it}} ; \beta\right)+\varepsilon_{\mathrm{it}}\right)$ proxies the highest feasible exports to or imports from country i respectively. The higher the $\mathrm{TRE}_{\mathrm{it}}$ is, the more efficient the exports/imports are, or closer to the frontier of exports/imports. The stochastic frontier gravity models are estimated by employing STATA version 13. In detail, this study used the time decay inefficiency built-in option (Battese \& Coelli, 1992) to estimate $\mathrm{u}_{\mathrm{it}}$ :

$$
u_{i t}=\eta_{i t} u_{i}=\left\{\exp \left[-\eta\left(t-T_{i}\right)\right]\right\} u_{i}
$$

$\eta$ is a scalar parameter to be estimated and can be used to determine whether the efficiency increases, is constant or decreases. The last period $(\mathrm{t}=\mathrm{T})$ for trade between Vietnam and country i contains the benchmark level of efficiency. If $\eta>0$, the level of efficiency increases towards the benchmark level or the impact of country-specific man-made policy constraint to exports/imports increases over time; If $\eta=0$ or is insignificant, the level of efficiency remains constant or the impact of country-specific man-made policy constraint to exports/imports stays unchanged over time.

This method also applies to the parameterization of Battese and Corra (1977), who replaced $\sigma_{\mathrm{u}}^{2}$ and $\sigma_{\mathrm{v}}{ }^{2}$ with $\sigma^{2}=\sigma_{\mathrm{u}}{ }^{2}+\sigma_{\mathrm{v}}{ }^{2}$ and $\gamma=\sigma_{\mathrm{u}}{ }^{2} /\left(\sigma_{\mathrm{u}}{ }^{2}+\sigma_{\mathrm{v}}{ }^{2}\right)$. It can be said that $\gamma$ must take the value between 0 and 1 . We can test whether we should put the error term $u$ in the form of stochastic frontier function, or not, by testing the significance of the $\gamma$ parameter. If the null hypothesis, that $\gamma$ equals zero, is rejected, this would mean that $\sigma_{u}{ }^{2}$ is non-zero and therefore the $u$ term should be added into the model, leading to a specification with parameters that should be consistently estimated using the stochastic frontier approach.

This study utilizes panel data consisting of 30 Vietnam's bilateral trading partners period 1995-2015, that account for an average of $85 \%$ total international trade with the world. Table 4 shows the list of countries included in this study which were selected based on their relative importance to Vietnam exports in different regions including ASEAN, ASEAN+3, NAFTA, the European Union, and Others (Australia, New Zealand, India, and Russia). The main reason this study takes this period is because Vietnam joined ASEAN in 1995. We use a variety of data sources. Exports/imports data is taken from the International Monetary Fund (Direction of Trade Statistics-DOTS). Gross Domestic Products (GDP), Population (POP), Real Effective Exchange Rate, and all product tariff rates are taken from the World Bank database. Data on the weighted distance measured in kilometers (D) and land area (Area) are taken from the Centre d'Etudes Prospectives et d'Informations Internationales (CEPII). The economic freedom index (EF) is taken from the Heritage Foundation. The list of ASEAN member countries was taken from official website asean.org. Export/import, gross domestic products, Real Effective Exchange Rate, and distance are transformed to logarithms. Table 6 in the appendix shows the estimation results of stochastic frontier gravity model. In general, the estimators are analogous to our expectation.

\section{Estimated Trade Efficiency}

Estimated trade efficiencies are shown in Table 1 and 2, whereas Figure 1 plots the trend. Table 1 describes the estimation with Asian pacific countries, consisting of eight ASEAN countries, China, Japan, Korea, and Russian plus India. According to the definition, the estimated trade efficiencies should lie between $0 \%$ and $100 \%$, where $100 \%$ implies that trade takes place at the frontier, the maximum possibility. In general, the empirical results infer that both export and import efficiencies of Vietnam improved considerably in period surveyed 1995-2015. Exports perform much more efficiently than imports do. The average export efficiency with ASEAN countries grew from $37.54 \%$ in the years between 1995 and 1999 to $48.73 \%$ in the period 2010-2015, while imports from ASEAN rose about one and a half times, from $19.94 \%$ to $33.41 \%$ in the same periods. In particular, the trade of Vietnam with Singapore outweighed $90 \%$, which is very near to the highest potential. On the other side, the trade efficiencies with Thailand and Indonesia were still less than 30\%, indicating that actual trade with these nations were far from the maximum likelihoods. The space for trade's growth are enormous. Due to the adverse effects of economic sanction imposed on Myanmar by the US, its trade efficiency with Vietnam was the least among ASEAN members, only below $5 \%$. 


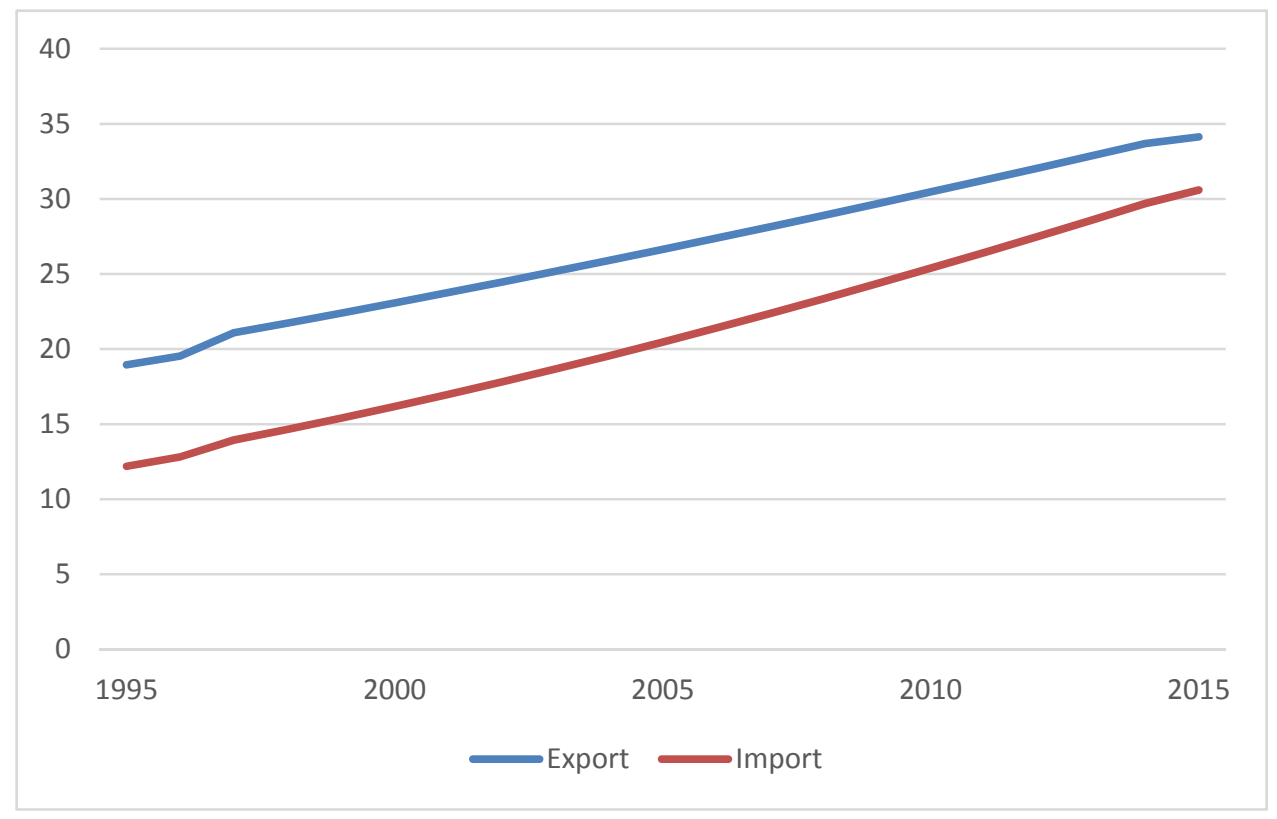

Figure 1. Trend of Vietnam's trade efficiencies (\%)

Table 1. Estimated Efficiencies of Vietnam's trade to Asia Pacific Countries + India (\%)

\begin{tabular}{ccccccccc}
\hline & \multicolumn{2}{c}{$1995-99$} & \multicolumn{2}{c}{$2000-04$} & \multicolumn{2}{c}{$2005-09$} & \multicolumn{2}{c}{$2010-15$} \\
\hline & Export & Import & Export & Import & Export & Import & Export & Import \\
\hline Singapore & 86.95 & 85.44 & 88.57 & 87.74 & 89.99 & 89.70 & 91.36 & 91.51 \\
Cambodia & 86.86 & 3.92 & 88.48 & 6.77 & 89.92 & 10.65 & 91.30 & 16.08 \\
Lao & 31.66 & 30.91 & 36.82 & 37.68 & 41.99 & 44.43 & 47.55 & 51.57 \\
Malaysia & 30.62 & 12.62 & 35.77 & 17.88 & 40.94 & 23.90 & 46.54 & 31.10 \\
Philippines & 30.53 & 2.42 & 35.68 & 4.52 & 40.85 & 7.62 & 46.45 & 12.24 \\
Thailand & 17.66 & 10.91 & 22.17 & 15.85 & 27.03 & 21.62 & 32.61 & 28.65 \\
Indonesia & 15.20 & 12.95 & 19.46 & 18.28 & 24.13 & 24.34 & 29.60 & 31.57 \\
Myanmar & 0.82 & 0.37 & 1.53 & 1.05 & 2.65 & 2.26 & 4.47 & 4.55 \\
ASEAN & 37.54 & 19.94 & 41.06 & 23.72 & 44.69 & 28.07 & 48.73 & 33.41 \\
Japan & 47.60 & 17.09 & 52.48 & 23.02 & 57.12 & 29.49 & 61.90 & 36.91 \\
Korea & 25.40 & 73.14 & 30.41 & 77.11 & 35.56 & 80.57 & 41.25 & 83.83 \\
China & 9.48 & 5.31 & 12.92 & 8.71 & 16.90 & 13.13 & 21.82 & 19.08 \\
Australia & 51.69 & 21.07 & 56.37 & 27.40 & 60.78 & 34.08 & 65.28 & 41.54 \\
Russia & 8.79 & 15.04 & 12.10 & 20.69 & 15.97 & 26.99 & 20.78 & 34.34 \\
New Zealand & 3.31 & 21.22 & 5.18 & 27.56 & 7.64 & 34.25 & 11.05 & 41.71 \\
India & 0.51 & 0.97 & 1.02 & 2.11 & 1.85 & 4.04 & 3.29 & 7.29 \\
\hline
\end{tabular}

Source: authors' calculation

Regarding Vietnam's trade with China, Japan, and Korea, while efficiency of exports to Japan is the highest, followed by that to Korea, at $61.9 \%$ and $41.25 \%$ respectively, that of imports from Korea ranks first, then Japan with the levels being $83.83 \%$ and $36.91 \%$ respectively. It is worth mentioning that until 2015 the trade with China was still less than one fourth of the estimated maximum possibility. Although ASEAN-China FTA came into force since 2005, Vietnam, as a member of ASEAN, could take the advantage of this FTA regarding trade. In terms of exports, due to the intensive competition of similar products made in China, Vietnamese goods with high labor intensity such as textiles can not compete successfully and are unable to augment the export volume in order to reach the highest likelihood, which is principally defined by the economic size of trading partners. It is odds that efficiency of imports from China was a mere $19.08 \%$ while import volumes from China accounts for one third. The reason may come from the gravity model's properties that claim that the higher the similarity between two countries is, the more efficient the trade is. China is 50 times in GDP and 15 times in population 
bigger than Vietnam. This reason is also used to explain why the efficiency of Vietnam's trade with India is very low, at only below $10 \%$. Moreover, the free trade agreement between ASEAN and India only came into effect several years ago, (2010) and it then has had a profound effect on trade flows between Vietnam and India. The Vietnam's export volume to India in 2010 and 2015 are twice and six times, respectively, higher than in 2009.

Table 2. Estimated Efficiencies of Vietnam's trade to EU and NAFTA members (\%)

\begin{tabular}{ccccccccc}
\hline & \multicolumn{2}{c}{$1995-99$} & \multicolumn{2}{c}{$2000-04$} & \multicolumn{2}{c}{$2005-09$} & \multicolumn{2}{c}{$2010-15$} \\
\hline Netherland & Export & Import & Export & Import & Export & Import & Export & Import \\
UK & 31.68 & 11.14 & 36.84 & 16.12 & 42.01 & 21.93 & 47.57 & 28.99 \\
Belgium & 18.49 & 4.62 & 23.08 & 7.76 & 27.98 & 11.93 & 33.59 & 17.65 \\
France & 17.49 & 8.88 & 33.25 & 19.27 & 38.43 & 25.44 & 44.08 & 32.72 \\
Italia & 13.68 & 15.99 & 17.77 & 21.78 & 22.29 & 28.16 & 27.65 & 35.55 \\
Spain & 9.14 & 7.80 & 12.51 & 11.98 & 16.43 & 17.13 & 21.30 & 23.70 \\
Poland & 8.96 & 2.30 & 12.29 & 4.34 & 16.19 & 7.35 & 21.03 & 11.89 \\
Sweden & 5.29 & 2.89 & 7.77 & 5.24 & 10.87 & 8.61 & 14.95 & 13.52 \\
Denmark & 5.06 & 8.04 & 7.49 & 12.29 & 10.52 & 17.50 & 14.54 & 24.12 \\
Finland & 4.22 & 7.47 & 6.40 & 11.57 & 9.18 & 16.64 & 12.93 & 23.14 \\
Germany & 1.72 & 4.31 & 2.93 & 7.32 & 4.66 & 11.37 & 7.24 & 16.96 \\
Greece & 1.40 & 0.08 & 2.44 & 0.26 & 3.98 & 0.71 & 6.32 & 1.78 \\
EU & 0.51 & 0.97 & 1.02 & 2.11 & 1.85 & 4.04 & 3.29 & 7.29 \\
USA & 9.80 & 6.21 & 13.65 & 10.00 & 17.03 & 14.23 & 21.21 & 19.78 \\
Canada & 25.47 & 7.17 & 30.48 & 11.18 & 35.63 & 16.17 & 41.32 & 22.61 \\
Mexico & 7.84 & 5.63 & 10.96 & 9.13 & 14.65 & 13.67 & 19.30 & 19.71 \\
NAFTA & 2.62 & 0.50 & 4.23 & 1.22 & 6.40 & 2.56 & 7.65 & 3.96 \\
\hline
\end{tabular}

Source: authors' calculation

Table 2 shows estimated efficiencies of Vietnam's trade with EU and NAFTA members. The general picture is that the trade efficiencies with both EU and NAFTA did not exceed one half of maximum level. Among EU members, the trade efficiencies with Netherland, UK, Belgium and France are 47.57\%, 33.59\%, 44.08\% and $27.65 \%$ respectively for exports and $28.99 \%, 17.65 \%, 32.72 \%$ and $35.55 \%$ respectively for imports. The remainders are below one fourth. By 2015, Vietnam's trade efficiency with EU are on average $21.21 \%$ and $19.78 \%$ for exports and import respectively. The efficiency with NAFTA's member countries is also moderate. In spite of the largest foreign market of Vietnam's goods (US 21.8\%; China 12.4\%, Japan 8.3\% in 2015), the export efficiency was only $41.32 \%$. Trade efficiency with Canada and Mexico were less than $20 \%$ and $10 \%$ of the maximum respectively. The estimation expresses that, if man-made trade resistances could be abolished, Vietnam's trade with those countries surveyed could grow substantially.

\section{Trade Efficiencies and AFTA}

Our estimation implies that, Vietnam's trade attained very high efficiency with a few countries such as Singapore, whereas performing at very low level with most of its trading partners, such as China, India, and Canada. In order to enhance the efficiency of Vietnam's trade, it is vital to identify driving determinants in diminishing the efficiency level. In this part, we employ regression analysis to discover those determinants. We consider the following regression models:

$$
\text { TRE_Export } i t=\delta_{0}+\delta_{1} \text { ASEAN }_{i}+\delta_{2} E F_{i t}+\delta_{3} T R_{i t}+\delta_{4} \text { LnREERVN }_{i t}+\varepsilon_{1 t}
$$

TRE_Import $_{i t}=\delta_{0}+\delta_{1} A S E A N_{i}+\delta_{2} E F_{i t}+\delta_{3} T R_{i t}+\delta_{4}$ LnREER $_{i t}+\delta_{5} E F V N_{t}+\delta_{6} T_{R V N_{t}}+\varepsilon_{2 t}$

In equation (6) and (7), ASEAN is the dummy variable, taking value one for the member of ASEAN, zero otherwise. $\mathrm{TR}_{\mathrm{it}}$ and $\mathrm{TRVN}_{\mathrm{t}}$ are the weighted tariff levied by country $\mathrm{i}$ and Vietnam to imports respectively. High tariffs reduce the Vietnam's trade efficiency. $\mathrm{EF}_{\mathrm{it}}$ and $\mathrm{EFVN}_{\mathrm{t}}$ are the indexes of economic freedom of country $\mathrm{i}$ and Vietnam at year $t$, which is a composite measure by the Heritage Foundations of ten factors, separated into four categories namely, rule of law, limited government, regulatory efficiency, and open market. The indexes take value between 0 and 100 with higher indexes implying lower trade barriers. While the higher economic freedom in Vietnam results in an increase in Vietnam import flows, the greater economic freedom for trading 
partners induces a lift in their foreign trade flows. Thus, both economic freedom in Vietnam and its partners are predicted to increase Vietnam's trade efficiency. REER $\mathrm{it}_{\mathrm{it}}$ and REERVN $\mathrm{t}_{\mathrm{t}}$ are the real effective exchange rate of country $i$ and Vietnam at year $t$. A devaluation of domestic currency is expected to boost exports and undermine imports.

Table 3. Determinants of Trade Efficiency

\begin{tabular}{ccc}
\hline Variables & TRE's Export & TRE's Import \\
\hline ASEAN & $0.321877^{* * *}$ & $0.145361^{* * *}$ \\
EF & $(0.019987)$ & $(0.023169)$ \\
& $0.007659^{* * *}$ & $0.006086^{* * *}$ \\
TR & $(0.000758)$ & $(0.000994)$ \\
& $-0.003449^{* * *}$ & $-0.001870^{*}$ \\
LnREERVN & $(0.001227)$ & $(0.001087)$ \\
LnREER & $-0.115654^{* *}$ & \\
EFVN & $(0.047863)$ & $0.042912^{*}$ \\
& & $(0.041244)$ \\
TRVN & & $0.003185^{*}$ \\
Constant & & $(0.003307)$ \\
& & $-0.00885^{* *}$ \\
\end{tabular}

Note: numbers in parentheses are standard errors.

*** significance at the $1 \%$ level; ** significance at the $5 \%$ level; * significance at the $10 \%$ level.

Table 3 shows the regression results. The estimated coefficients of ASEAN are 0.3219 and 0.1453 for export and import respectively and all statistically significant at $1 \%$ level, suggesting that the ASEAN membership contributes positively to the Vietnam's trade efficiency. The estimated coefficients of tariff are negative and statistically significant, implying that tariffs levied by trading partners or by Vietnam plays as one of driving factors to undermine the trade efficiency between Vietnam and those countries. The trading partners' economic freedom significantly raised trade efficiency, diminishing the gap between the actual and potential trade. Vietnam's economic freedom coefficient is significant and positive, which reflected the achievements of Vietnam Economic Reform, the so-called "Doi Moi". The coefficient of LnREER is 0.0429 and significant at $10 \%$ level, whereas that of LnREERVN is -0.1157 and significant at $5 \%$. It means that Vietnam can not enjoy the benefits from domestic currency's devaluation as its trading partners do. The low competitive ability of Vietnam's products is the main reason. Moreover, the loss of Vietnam dong value increases the price of imported inputs mainly used to produce exporting goods, which further deteriorates the competitive ability of Vietnam's exports.

It is worthy to explain the reason why export efficiency exceeds import's as we saw in Figure 1. The adverse effects of Vietnam's trade balance deficit in the long term lead to a gap between exports and imports barriers. Trade deficit comes from the prolonged severe imbalance in the structure of export's and import's goods. To reduce the trade deficit, Vietnam in the past two decades has adjusted the exchange rate policy, implemented the restructuring of import and export goods, improved the institutional environment, and provided policies that promoted export industries. As a result, the export barriers are lower than those of import, reflecting the export-oriented industrialization of Vietnam. Vietnam's government has continued to implement policies restricting imports to protect domestic industries, the average tax rates of Vietnam are twice higher than its trading partners (11.4\% versus 5.7\%) (World Bank tariff database). Moreover, regression results showed that the absolute value of estimated coefficients of TRVN is five times higher than that of Tariff, lowering import efficiency much more than export efficiency.

\section{Concluding Remarks}

In this paper, we estimated the trade efficiency of Vietnam with its major trading partners and determined factors which affect Vietnam's trade efficiency. Stochastic gravity model was employed with data from 30 countries in the period 1995-2015. Our empirical results indicate that, Vietnam's trade is much below the highest potentials and exports contribute more to the overall efficiency than imports do. Although increasing over periods surveyed, 
the Vietnam's trade efficiencies are still very modest, with the average number being around $30 \%$ in 2015 . This implies that there is still large room for improving trade relation between Vietnam and its trading partners. Vietnam's trade efficiencies with AFTA members are much higher than with EU and NAFTA. This indicates that there is a need to improve Vietnam's trade with EU and NAFTA because they are the main trading partners of Vietnam.

Our study reveals that joining AFTA and relaxing economic constraints help to enhance Vietnam's trade efficiency, while imposing tariffs and devaluating Vietnam dong undermines it. The benefits of entering AFTA become evident; the success of Vietnam's 1986 economic reform improves the economic environment and increases the trade efficiency. While tariffs are of importance to protect the domestic industries, especially the infant ones, in general they can hinder the Vietnam's trade efficiency. Due to the weak competition of export products, Vietnam can not enjoy the benefit derived from domestic currency devaluation. Our empirical results also suggest some policy implication. To improve the Vietnam's trade efficiency, it is vital that Vietnam should join more regional FTAs, improve economic freedom, cut tariffs and improve the competitive ability of its products to take the advantage of domestic currency devaluation.

\section{References}

Abrams, R. K. (1980). International Trade Flows under Flexible Exchange Rates. Federal Reserve Bank of Kansas City. Economic Review, 65(3), 3-10. Retrieved from https://www.kansascityfed.org/PUBLICAT/econrev/EconRevArchive/1980/1q80abra.pdf

Aghdaie, S. F. A., Seidi, M., \& Riasi, A. (2012). Identifying the barriers to Iran's Saffron export by using Porter's diamond model. International Journal of Marketing Studies, 4(5), 129-138. https://doi.org/10.5539/ijms.v4n5p129

Anderson, J. E., \& Van Wincoop, E. (2003). Gravity with gravitas: a solution to the border puzzle. The American Economic Review, 93(1), 170-192. https://doi.org/10.1257/000282803321455214

Aitken, N. D. (1973). The Effect of EEC and EFTA on European Trade: A Temporal Cross-Section Analysis. American Economic Review, 5, 881-892. http://www.jstor.org/stable/1813911

Armstrong, S. (2007). Measuring Trade and Trade Potential: A Survey. Asia Pacific Economic Papers, No. 368, 1-19. https://doi.org/10.2139/ssrn.1760426

Baier, S. L., \& Bergstrand, J. H. (2009). Bonus vetus OLS: A simple method for approximating international trade-cost effects using the gravity equation. Journal of International Economics, 77(1), 77-85. https://doi.org/10.1016/j.jinteco.2008.10.004

Battese, G. E., \& Coelli, T. (1992). Frontier Production Functions, Technical Efficiency and Panel Data: with Application to Paddy Farmers in India. Journal of Productivity Analysis, 3(1/2), 153-169. https://doi.org/10.1007/BF00158774

Battese, G., \& Corra, G. S. (1977). Estimation of A Production Frontier Model: With Application to the Pastoral Zone of Eastern Australia. Australian Journal of Agricultural Economics, 21(3). https://doi.org/10.1111/j.1467-8489.1977.tb00204.x

Bergstrand, J. H. (1985). The Gravity Equation in International Trade: Some Microeconomic Foundations and Empirical Evidence. Review of Economics and Statistics, 67(3), 474-81. https://doi.org/10.2307/1925976

Brade, J. C., \& Mendez, J. A. (1983). Regional Economic Integration and the Volume of Intra-regional Trade: A Comparison of Developed and Developing Country Experience. Kyklos. 36(4), 589-603. Retrieved from https://asu.pure.elsevier.com/en/publications/regional-economic-integration-and-the-volume-of-intra-region al-tr

Frankel, J., Stein, E., \& Wei, S. J. (1996). Regional Trading Agreements: Natural or Supernatural? American Economic Review, 86(2), 52-56. http://users.nber.org/ wei/data/fsw1996/fsw1996.pdf

Head, K., \& Mayer, T. (2010). Illusory Border Effects: Distance Mismeasurement Inflates Estimates of Home Bias in Trade. The gravity model in international trade: Advances and applications, 165-192.

Kalirajan, K., \& Findlay, C., (2005). Estimating Potential Trade Using Gravity Models: A Suggested Methodology. Foundation for Advanced Studies on International Development, Tokyo.

Le, Q. P., Nguyen, D. T., \& Bandara, J. S. (1996). Vietnam's foreign trade in the context of ASEAN and the Asia-Pacific region: a gravity approach. ASEAN Economic Bulletin, 185-199. https://doi.org/10.1355/ae13-2c 
Linnemann, H. (1966). An econometric study of international trade flows (Vol. 234). Amsterdam: North-Holland Publishing Company.

Narayan, S., \& Nguyen, T. T. (2016). Does the trade gravity model depend on trading partners? Some evidence from Vietnam and her 54 trading partners. International Review of Economics \& Finance, 41, 220-237. https://doi.org/10.1016/j.iref.2015.08.010

Nguyen, T. K. (2009). Gravity model by panel data approach: an empirical application with implications for the ASEAN free trade area. ASEAN Economic Bulletin, 26(3), 266-277. https://doi.org/ 10.1355/ae26-3c

Riasi, A. (2015). Barriers to international supply chain management in Iranian flower industry. Management Science Letters, 5(4), 363-368. http://dx.dox.org/10.5267/j.msl.2015.2.005

Riasi, A., \& Amiri Aghdaie, S. F. (2013). Effects of a hypothetical Iranian accession to the world trade organization on Iran's flower industry. Consilience: The Journal of Sustainable Development, 10(1), 99-110. https://doi.org/10.7916/D8HQ3ZK8

Thanh, V. T., \& Duong, N. A. (2011). Revisiting exports and foreign direct investment in Vietnam. Asian Economic Policy Review, 6(1), 112-131. https://doi.org/10.1111/j.1748-3131.2011.01187.x

Tinbergen, J. (1962). Shaping the World Economy: Suggestions for an International Economic Policy, The Twentieth Century Fund, New York. https://doi.org/ 10.2307/2229041

Wall, H. J. (1999). Using the gravity model to estimate the costs of protection. Review-Federal Reserve Bank of Saint Louis, 31, 33-40. http://citeseerx.ist.psu.edu/viewdoc/download?doi=10.1.1.6.5455\&rep=rep1\&type=pdf

Xuan, N. T., \& Xing, Y. (2008). Foreign direct investment and exports The experiences of Vietnam. Economics of transition, 16(2), 183-197. https://doi.org/10.1111/j.1468-0351.2008.00321.x

\section{Appendix}

Table 4. Vietnam's Trading Partners

\begin{tabular}{ccccc}
\hline Region/Country & & & Region/Country \\
\hline ASEAN & & EU & BEL \\
\hline Indonesia & IDN & KHM & Germany & DEU \\
Cambodia & LAO & Denmark & DNK \\
Lao PDR & MMR & Spain & ESP \\
Myanmar & MYS & Finland & FIN \\
Malaysia & PHL & France & FRA \\
Philippines & SGP & United Kingdom & GBR \\
Singapore & THA & Greece & GRC \\
Thailand & & Italy & ITA \\
ASEAN+3 & CHN & Netherlands & NLD \\
China & JPN & Poland & POL \\
Japan & KOR & Sweden & SWE \\
Korea, Rep. & & Others & Australia \\
NAFTA & CAN & NEX & New Zealand & Russia \\
Canada & India & NZL & RUS \\
Mexico & & IND &
\end{tabular}

Table 5. Statistical Summary

\begin{tabular}{ccccccc}
\hline Variable & Mean & Std. Dev. & Min & Max & Source & Expected signs \\
\hline LnEX & 19.726 & 1.902 & 11.314 & 24.265 & Tinbergen (1962) & \\
LnIM & 19.458 & 2.087 & 9.210 & 25.013 & Tinbergen (1962) & + \\
LnGDP & 26.736 & 1.828 & 20.970 & 30.518 & Tinbergen (1962) & + \\
\hline
\end{tabular}




\begin{tabular}{ccccccc}
\hline LnGDPVN & 24.854 & 0.727 & 23.755 & 25.989 & Tinbergen (1962) & + \\
LnD & 8.434 & 1.011 & 5.861 & 9.608 & Tinbergen (1962) & - \\
PVN & 82.193 & 5.844 & 71.995 & 91.703 & Linnemann (1966) & + \\
P & 136.722 & 298.541 & 3.524 & 1371.22 & Linnemann (1966) & + \\
EF & 66.1 & 10.299 & 33.5 & 89.4 & Wall (1999) & + \\
EFVN & 46.925 & 4.246 & 38.6 & 51.7 & Wall (1999) & + \\
TR & 5.763 & 5.974 & 0 & 56.4 & Linnemann (1966) & - \\
TRVN & 11.434 & 3.487 & 6.63 & 15.57 & Linnemann (1966) & + \\
LnREER & 4.606 & 0.300 & 2.497 & 7.136 & Anderson \& Wincoop (2003) & + \\
LnREERVN & 4.705 & 0.149 & 4.478 & 4.978 & Anderson \& Wincoop (2003) & + \\
\hline
\end{tabular}

Source: Author's calculation based on data collection

Table 6. Maximum Likelihood Estimates of the Stochastic Gravity

\begin{tabular}{ccc}
\hline Variable & LnEX & LnIM \\
\hline LnGDP & $0.503168^{* * *}$ & $0.6721288^{* * *}$ \\
& $(.104739)$ & $(0.072789)$ \\
LnGDPVN & $1.35851^{* * *}$ & $0.810126^{* *}$ \\
& $(0.355574)$ & $(0.330268)$ \\
LnD & $-0.364271^{* *}$ & $(0.109884)$ \\
& $(0.1433375)$ & $0.471919^{* * *}$ \\
PVN & $1.12^{* * *}$ & $(0.132605)$ \\
& $(0.135695)$ & $0.001323^{* * *}$ \\
P & $0.001015^{* *}$ & $(0.000302)$ \\
& $(.000479)$ & $-0.711911^{* *}$ \\
LL & -0.222649 & $(0.324108)$ \\
& $(0.329801)$ & $-0.504946^{* * *}$ \\
T & $-1.13867^{* * *}$ & $(0.157479)$ \\
& $(0.162831)$ & $-39.92446^{* *}$ \\
Constant & $-102.6388^{* * *}$ & $(16.06557)$ \\
& $(16.63973)$ & $1.289445^{* * *}$ \\
Mu & $1.098108^{* *}$ & $(0.307328)$ \\
Eta & $(0.447988)$ & $0.037003^{* * *}$
\end{tabular}

Note: Values in parentheses () are standard errors. *** Significant at the 1 per cent level; ** Significant at 5 per cent level; $*$ Significant at 10 per cent level.

\section{Copyrights}

Copyright for this article is retained by the author(s), with first publication rights granted to the journal.

This is an open-access article distributed under the terms and conditions of the Creative Commons Attribution license (http://creativecommons.org/licenses/by/4.0/). 